\title{
Post-breeding dispersal of Adélie penguins (Pygoscelis adeliae) nesting at Signy Island, South Orkney Islands
}

\author{
M. J. Dunn · J. R. D. Silk • P. N. Trathan
}

Received: 7 May 2010/Revised: 6 July 2010/Accepted: 14 July 2010/Published online: 25 July 2010

(C) The Author(s) 2010. This article is published with open access at Springerlink.com

\begin{abstract}
ARGOS satellite telemetry and Global Location Sensors (geolocators) were used to identify the moult locations and the winter foraging dispersal of Adélie penguins after they left their breeding colonies on Signy Island in the South Orkney Islands. Animals were tracked during the period December 2004 to October 2005. All birds displayed a similar pattern of migratory behaviour, remaining away from colonies for approximately 9 months, at distances of up to 2,235 km. Moult locations were within the pack ice. Mean daily travel speeds to the moult locations were significantly faster when moving through open water than through pack ice. Moult occurred during February/March within a narrow latitudinal range $\left(65-71^{\circ} \mathrm{S}\right)$, at a mean distance of $126 \mathrm{~km}$ from the ice edge; the mean duration of individual moult was c. 18.6 days. After moult, penguins spent the subsequent winter months moving north or north-eastward within the expanding winter pack ice, at a mean distance of $216 \mathrm{~km}$ from the ice edge, and in areas with ice cover $>80 \%$. The penguins returned to the vicinity of their colony between September 26 and October 22, 2005. This dependence of Adélie penguins on sea ice habitat suggests that any further reductions in sea ice extent in the Weddell Sea region would potentially have important impacts on the population processes of this pagophilic species.
\end{abstract}

Keywords Pygoscelis adeliae - South Orkneys . Moult · Wintering · Satellite telemetry · Geolocation . Tracking

M. J. Dunn ( $₫)$ · J. R. D. Silk · P. N. Trathan

British Antarctic Survey, Natural Environment Research

Council, Madingley Road, Cambridge CB3 OET, UK

e-mail: mdunn@bas.ac.uk

\section{Introduction}

Numerous studies from the West Antarctic Peninsula and the Scotia Sea have provided strong evidence for recent, rapid, regional warming across the sector, with consequent reductions in seasonal sea ice (Murphy et al. 1995; Vaughan et al. 2001; Gille 2002; Cook et al. 2005; Clarke et al. 2007; Ducklow et al. 2007; Stammerjohn et al. 2008a, 2008b). Further, variations in the timing of sea ice coverage have been linked to physical forcing driven by the El Niño-Southern Oscillation (ENSO) and Southern Annular Mode (SAM) (Yuan and Martinson 2000; Yuan 2004; Turner 2004; Stammerjohn et al. 2008b). Indeed, this environmental perturbation is now thought to be generating ecological responses in numerous species, including Antarctic penguin populations (Croxall et al. 2002; Smith et al. 2003; Forcada et al. 2006; Forcada and Trathan 2009).

This situation supports assertions that penguin population size can be used as an indicator of ecosystem change (Fraser et al. 1992; Croxall et al. 2002; Hinke et al. 2007; Boersma 2008; Forcada and Trathan 2009). Long-term population studies of Adélie penguins (Pygoscelis adeliae) breeding at Signy Island in the South Orkney Islands have shown an irregular annual decline in numbers over the period 1987-2010 (BAS unpublished data), in parallel with regional warming and reduction in the seasonal sea ice (Forcada et al. 2006, 2008; Turner et al. 2009). Thus, as penguin population size and reproductive performance are known to be related to sea ice, weather and oceanographic conditions (Trathan et al. 1996; Forcada and Trathan 2009), understanding how they utilize their environment and available resources is critical. Indeed, if we are to understand penguin population processes, we need a mechanistic understanding of their interactions with their habitat, rather than simply a correlational analysis. 
As a true Antarctic species, the distribution of Adélie penguins is closely linked with sea ice (Lishman 1985; Ainley et al. 1994; Kerry et al. 1995; Trathan et al. 1996; Croxall et al. 2002; Clarke et al. 2003; Lynnes et al. 2004; Ballard et al. 2010), and studies have indicated that winter conditions are a key driver for certain population processes (Trathan et al. 1996; Jenouvrier et al. 2006; Hinke et al. 2007; Ballard et al. 2010). In particular, Adélie penguins are associated with the marginal ice zone (MIZ), which typically extends for c. $100 \mathrm{~km}$ from the edge of the pack ice (Croxall et al. 2002). In winter, Adélie penguins are thought to feed on small fish and Antarctic krill Euphausia superba, the latter also being one of the key summer diet species in the West Antarctic Peninsula and Scotia Sea (Ainley et al. 1994, 1998). The population dynamics of Antarctic krill are also influenced by environmental conditions, including annual change in sea ice extent and duration (Quetin and Ross 2001, 2003; Atkinson et al. 2004, 2008; Murphy et al. 2007), so information on their biomass and distribution is of major importance in understanding penguin population trajectories in the West Antarctic Peninsula and Scotia Sea sectors (Lishman 1985; Fraser and Hofmann 2003; Lynnes et al. 2004; Forcada et al. 2006; Hinke et al. 2007). Consequently, knowledge of the winter foraging distribution and behaviour of Adélie penguins is important if the relationships between sea ice, prey abundance and population mechanisms, together with climate-mediated change, are to be properly understood.

Although there are a number of studies examining the summer foraging range of Adélie penguins (e.g. Kerry et al. 1995; Clarke et al. 1998, 2003; Wienecke et al. 2000; Lynnes et al. 2002), until recently little was known about the winter movements of this species (Ballard et al. 2010). Previous studies have deployed ARGOS satellite transmitters (Platform Transmitter Terminals or PTTs) on small numbers of adult and fledgling Adélie penguins to investigate their post-breeding dispersal (Kerry et al. 1995; Davis et al. 1996, 2001; Clarke et al. 2003) but limited battery life and the need to attach such devices to feathers which are subsequently shed at moult has meant that complete movement over the winter period cannot be documented. In recent years, however, technological advances have resulted in the production of miniature Global Location Sensor (GLS) loggers; battery-powered devices that enable the movements of seabirds to be tracked on a year round basis (Phillips et al. 2004; Bost et al. 2009; Ballard et al. 2010).

This study involved the deployment of both PTTs and GLS loggers to determine the at-sea winter dispersal of post-breeding adult Adélie penguins at Signy Island, South Orkney Islands. The aim was to identify the key habitats used by this species during the non-breeding period.

\section{Materials and methods}

Sea ice concentration and extent

Regional daily sea ice concentration maps at $6.25 \mathrm{~km}$ resolution, calculated with the ARTIST Sea Ice (ASI) algorithm using AMSR-E (Advanced Microwave Scanning Radiometer) data (Spreen et al. 2008), were obtained from the Institute of Environmental Physics at Bremen University (http://iup.physik.uni-bremen.de:8084). Daily and monthly composite maps of marginal sea ice extent in the Weddell Sea area, corresponding to $15 \%$ ice concentration, were derived from the daily images.

Study site and species

The study was carried out on Adélie penguins breeding at Gourlay Peninsula and North Point, Signy Island, South Orkney Islands $\left(60^{\circ} 42^{\prime} \mathrm{S}, 45^{\circ} 36^{\prime} \mathrm{W}\right.$, Fig. 1$)$. Approximately 16,900 pairs of Adélie penguins breed on Signy Island, of which 10,200 and 4,600 pairs breed on the Gourlay Peninsula and at North Point, respectively (BAS unpublished data 2006).

\section{Deployment of devices}

During the late crèche period (December 17, 2004-January 17, 2005), five adult Adélie penguins were captured at North Point, immediately after feeding their chicks. We attached one of two types of PTT to the lower medial portion of the back of each penguin using Tesa ${ }^{\circledR}$ tape, plastic cable ties and two part quick-set epoxy resin, using methods similar to those of Wilson et al. (1997). PTTs were either KiwiSat 101 transmitters $(125 \times 43 \times 20 \mathrm{~mm}$, $107 \mathrm{~g})$ or KiwiSat ST10 transmitters $(135 \times 32 \times 18 \mathrm{~mm}$, $107 \mathrm{~g})$. All PTTs were hydrodynamically shaped to reduce

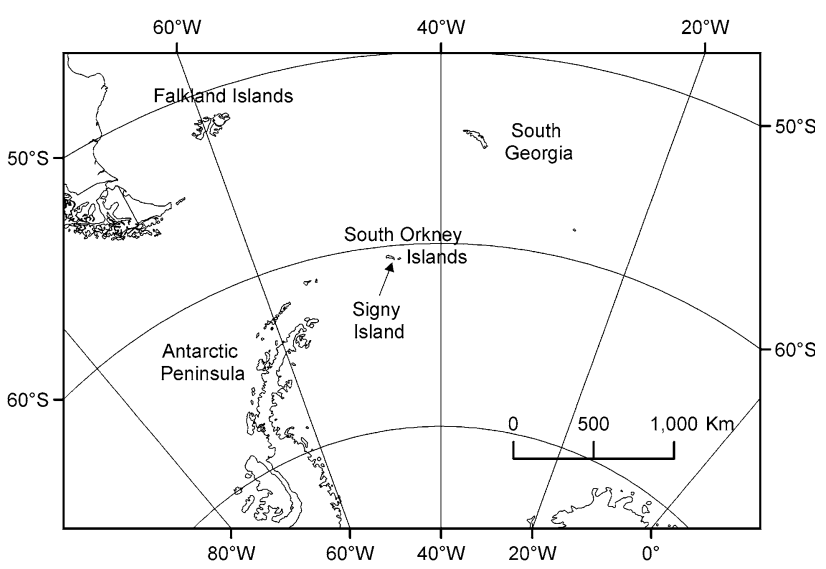

Fig. 1 Map showing the location of the study site 
drag (Culik et al. 1994). Each was set to transmit every $45 \mathrm{~s}$ and was equipped with a saltwater switch. These switches stop the instrument from transmitting after a 3-h period out of water (a means of conserving battery power) and only reactivate after re-submergence. Following the attachment procedure, the penguins were released close to their nest sites. All devices were lost during the moult.

During the late crèche period, we also deployed 54 combined Global Location Sensor (GLS-immersion) data loggers (Afanasyev 2004) on adult Adélie penguins captured immediately after feeding their chicks at Gourlay Peninsula. We used 15 MK4 $(25 \times 21 \times 7 \mathrm{~mm}, 5 \mathrm{~g})$ and 39 MK3 $(22 \times 19 \times 12 \mathrm{~mm}, 9 \mathrm{~g})$ loggers which were secured by metal cable tie to plastic leg bands fitted to the tarsus. Care was taken to ensure that there was sufficient freedom of movement to prevent constriction of the leg by the band or abrasion of the skin. GLS devices were recovered during the brood guard and crèche periods the following breeding season.

Location data analysis

PTT location data were obtained from the ARGOS system. Following the approach adopted in previous studies (Barlow and Croxall 2002; Lynnes et al. 2002), only PTT fixes of ARGOS Location Class (LC) 3, 2, 1 and 0 were used, corresponding to a radius of error of better than $1,500 \mathrm{~m}$ for LC 1-3 and over 1,500 $\mathrm{m}$ for LC 0 (www.argossystem.org). An iterative filter (McConnell et al. 1992) was applied to remove unlikely locations based on a maximum travel speed of $8 \mathrm{~km} \mathrm{~h}^{-1}$ (Ainley 2002). The validated fixes of LC 1-3 were then used in the calculation of cumulative travel distance and maximum distance from the colony for each bird. Due to the considerable levels of variability in the interval between fixes, a single fix per day (the fix closest to midnight) was used to compute overall daily travel speeds for comparison between birds, and for comparison during periods when the entire day was spent within sea ice ( $>15 \%$ ice concentration) or entirely in open water.

The GLS loggers measured the intensity of visible light every minute and tested for saltwater immersion every three-seconds. At the end of each 10-min period, the maximum (truncated) light reading and the sum of positive saltwater tests (between 0 and 200, where 0 indicates that the logger was always dry and 200 that it was always wet) were recorded (Afanasyev 2004). Light level data were processed following the approach of Phillips et al. (2004). The times of sunrise and sunset were determined from thresholds in the light curves and converted to location estimates using TransEdit and BirdTracker (British Antarctic Survey, Cambridge, UK); latitude was derived from day length and longitude from the time of local noon. Obvious interruptions to the light curves around dawn and dusk were noted during processing and the resulting locations were later excluded if obviously erroneous. During the equinoxes (20 March-22 September), it is difficult or nearly impossible to estimate latitude using this method, so locations were unavailable for up to 4 weeks around these times. The mean accuracy of the GLS loggers has been shown to be around $186 \mathrm{~km}$ (Phillips et al. 2004) and, although the location data are highly effective for tracking large scale migration, calculations of distance and velocity should be considered as approximate.

Plots of immersion data allowed for the easy identification of long periods when the loggers were continuously dry, indicating that the bird was on ice or on dry land. In all cases, there was an extended dry period during February and March that we assumed to indicate the moult. As there was considerable interference in light data collected during this period, presumably because birds were sitting on the logger or feathers were obscuring the sensor, few valid locations were obtained. The moult location for each penguin was therefore estimated from between 1 and 7 (mean of 3, $n=19$ ) locations collected immediately prior to, during, or following this period.

Weekly location estimates (the average of all valid locations) were used in calculations of the maximum distance travelled from the colony, travel speed, mean distance from the ice edge (indicated by the $15 \%$ contour for the mid-week daily sea ice map) and ice concentration (the mean value of all cells within a circle of radius $50 \mathrm{~km}$ for the mid-week daily sea ice map). Mean values for these parameters are presented for birds for which we have complete GLS tracks from April to August $(n=15)$; values from all appropriate weekly locations were used for the monthly estimates. The mean distance from ice edge and ice concentration for each moult location was averaged from the values calculated for each week of the 3-week moult period.

Most phenological information (departure from the colony, start of return migration, arrival in the vicinity of the colony etc.) were derived from the geolocation data (from longitude only, if latitudes were unavailable because of the equinox). Exceptions to this were the onset and completion of moult and the first night spent on land (i.e. return to the nest site), which were based on the immersion data. No personnel were present on Signy Island during September-October 2005 preventing direct observation of returning birds.

Great-circle distances were used for all distance calculations, and statistical calculations were performed using Minitab ${ }^{\circledR}$ 14.1 Statistical Software for Windows (www. minitab.com). Results are presented as means \pm SD unless otherwise stated. 


\section{Results}

Sea ice extent

Regional seasonal sea ice was at its minimum extent in February 2005, and restricted to the western Weddell Sea south of $63^{\circ} \mathrm{S}$ and west of $32^{\circ} \mathrm{W}$. In mid-March, the ice in the Weddell Sea began to extend northward and eastwards, joining with the seasonal sea ice spreading northwards from the continent, until it reached $60^{\circ} \mathrm{S}$ by mid-May. Northward expansion was maintained during the subsequent months and the sea ice reached its maximum extent, at approximately $56^{\circ} \mathrm{S}$, in mid-September.

\section{Satellite-tracking}

Migration tracking data were obtained from all five PTTs although the track for bird 5 was partial (no locations were obtained for the first 7 days after the bird departed the colony, on January 28,2005 , and the instrument ceased to transmit after 12 days). The other four penguins departed the colony between December 25, 2004, and January 3, 2005, and were tracked for an average of 49 days (Table 1). As they travelled south, these four penguins encountered a band of sea ice at approximately $63^{\circ} \mathrm{S}$ at which they took a more easterly route as they travelled along and then through the northern edge of the ice (Fig. 2a). Once in open water again their tracks converged and all five birds entered the main pack at approximately $67.5^{\circ} \mathrm{S}$ within a narrow longitudinal range $\left(43.7-41.4^{\circ} \mathrm{W}\right.$, mean $42.4^{\circ} \mathrm{W}$, Fig. 2 b). The birds continued south through the eastern edge of the ice until a prolonged period out of water and/or battery failure caused the instruments to cease transmission.

During the tracking period, birds travelled between 823 and $2,172 \mathrm{~km}$, at a mean daily travel speed of
$34.2 \pm 25.5 \mathrm{~km} \mathrm{~d}^{-1}$, to reach locations at a mean maximum distance of $1,000 \mathrm{~km}$ from the colony (Table 1). All birds achieved travel speeds of over $100 \mathrm{~km}$ per day within

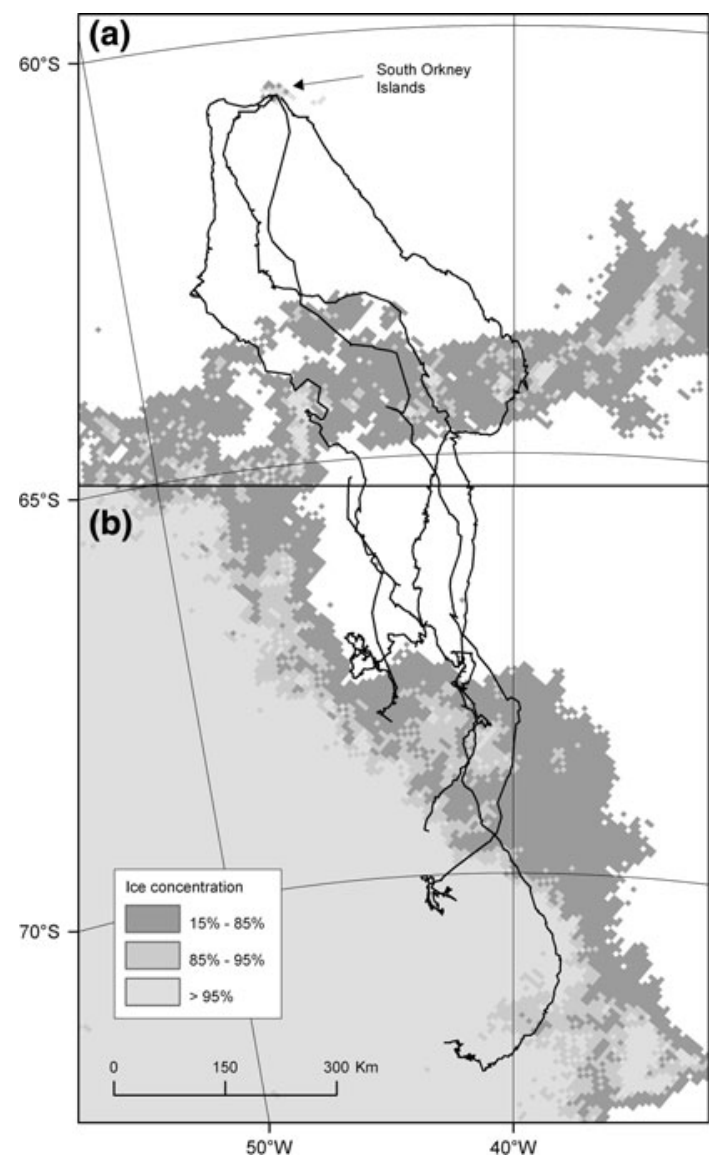

Fig. 2 Routes of five Adélie penguins (1 partial), tracked using PTTs, from Signy Island during the post-breeding winter dispersal (December 2004-February 2005) overlaid on representative ice concentration maps for the a early (9 January 2005) and b latter (6 February 2005) stages of the journey

Table 1 Trip characteristics of 5 adult Adélie penguins tracked using PTTs from North Point, Signy Island

\begin{tabular}{|c|c|c|c|c|c|c|c|c|}
\hline Bird & $\begin{array}{l}\text { Departure } \\
\text { date }\end{array}$ & $\begin{array}{l}\text { Last } \\
\text { transmission } \\
\text { date }\end{array}$ & $\begin{array}{l}\text { Trip } \\
\text { duration } \\
\text { (d) }\end{array}$ & $\begin{array}{l}\text { Total } \\
\text { distance } \\
\text { tracked } \\
(\mathrm{km})\end{array}$ & $\begin{array}{l}\text { Max. } \\
\text { distance } \\
\text { from colony } \\
(\mathrm{km})\end{array}$ & $\begin{array}{l}\text { Travel speed } \\
\left(\mathrm{km} \mathrm{d}^{-1}\right)\end{array}$ & $\begin{array}{l}\text { Open water travel } \\
\text { speed }\left(\mathrm{km} \mathrm{d}^{-1}\right)\end{array}$ & $\begin{array}{l}\text { Within ice travel } \\
\text { speed }\left(\mathrm{km} \mathrm{d}^{-1}\right)\end{array}$ \\
\hline 1 & $\begin{array}{r}03 / 01 / \\
2005\end{array}$ & $15 / 02 / 2005$ & 43 & 2,130 & 827 & $\begin{array}{l}32.0 \pm 28.4 \\
\quad(2.2-113.0)(n=43)\end{array}$ & $\begin{array}{l}40.8 \pm 35.6(2.2-113.0) \\
\quad(n=22)\end{array}$ & $\begin{array}{l}20.7 \pm 9.7(3.2-30.4) \\
\quad(n=9)\end{array}$ \\
\hline 2 & $\begin{array}{r}28 / 12 / \\
2004\end{array}$ & $25 / 02 / 2005$ & 59 & 1,712 & 1,093 & $\begin{array}{l}31.3 \pm 21.3 \\
\quad(4.7-103.4)(n=41)\end{array}$ & $\begin{array}{l}46.8 \pm 30.9 \\
\quad(10.9-103.4)(n=10)\end{array}$ & $\begin{array}{l}25.5 \pm 16.2(4.7-56.1) \\
\quad(n=23)\end{array}$ \\
\hline 3 & $\begin{array}{r}26 / 12 / \\
2004\end{array}$ & $17 / 02 / 2005$ & 53 & 1,869 & 979 & $\begin{array}{l}26.7 \pm 21.6 \\
\quad(2.5-122.8)(n=52)\end{array}$ & $\begin{array}{l}39.0 \pm 28.1(7.7-122.8) \\
\quad(n=15)\end{array}$ & $\begin{array}{l}23.5 \pm 18.9(2.5-55.9) \\
\quad(n=19)\end{array}$ \\
\hline 4 & $\begin{array}{r}25 / 12 / \\
2004\end{array}$ & $07 / 02 / 2005$ & 44 & 2,172 & 1,309 & $\begin{array}{l}42.3 \pm 24.3 \\
\quad(3.9-102.0)(n=39)\end{array}$ & $\begin{array}{l}49.1 \pm 29.1(4.9-102.0) \\
\quad(n=11)\end{array}$ & $\begin{array}{l}35.1 \pm 21.1(3.9-61.2) \\
\quad(n=22)\end{array}$ \\
\hline 5 & $\begin{array}{l}28 / 1 / \\
2005\end{array}$ & $09 / 02 / 2005$ & 12 & 823 & 791 & $\begin{array}{l}38.5 \pm 33.6(4.6-76.3) \\
\quad(n=5)\end{array}$ & $\begin{array}{l}47.0 \pm 32.1(11.7-76.3) \\
\quad(n=4)\end{array}$ & $4.6(n=1)$ \\
\hline
\end{tabular}

Travel speeds are mean \pm SD with range in parenthesis 
Fig. 3 Moult locations of 19 adult Adélie penguins from Signy Island overlaid on a representative ice concentration map for the mid-moult period (mean of daily maps for 21 February, 28 February and 7 March 2005)

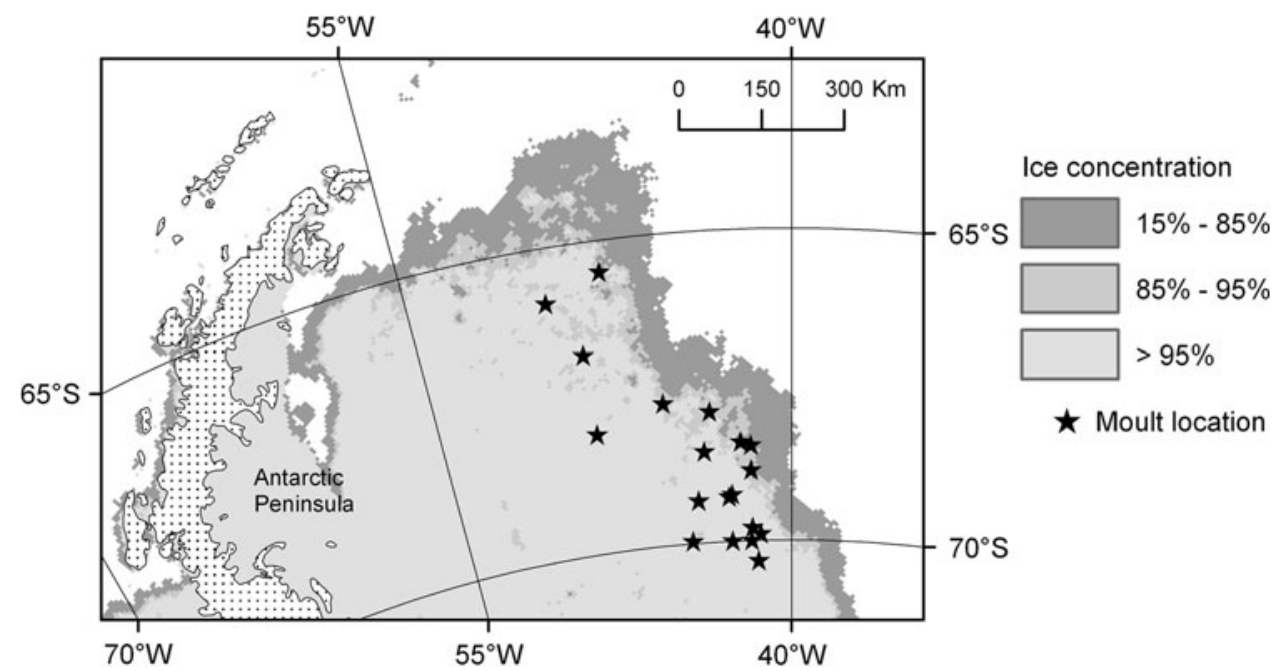

a few days of their departure from Signy Island (excluding bird 5 for which there are no data). Daily travel speeds were significantly faster when moving through open water, compared to sea ice (Kruskal-Wallis Test $H 1=9.62$, $P<0.05$, median $=33.6 \pm 31.0 \mathrm{~km} \mathrm{~d}^{-1}$ open water, $21.8 \pm 18.5 \mathrm{~km} \mathrm{~d}^{-1}$ within sea ice).

\section{Global location sensor tracking}

During November and December 2005, 28 (52\%) of the penguins that had been fitted with GLS loggers were recaptured and 21 loggers were recovered; seven birds had lost their logger and only the leg band remained. 20 GLS loggers downloaded successfully, although the data were incomplete in six cases, and one device was found to have completely failed. Twenty-three of the 28 penguins showed evidence of skin abrasion and in some cases feather loss caused by the bands.

Birds departed the colony between January 12 and February 4, 2005 (mean 24 January, $n=18$ ). Their route south overlapped the migratory route taken by the five PTT-tracked Adélie penguins and their average travel speed from the point of departure to the estimated moult location was similar $\left(31 \pm 10 \mathrm{~km} \mathrm{~d}^{-1}\right)$. Penguins started their moult approximately 4 weeks after departing the colony (mean start date 19 February, range 7 February-3 March, $n=19$ ) and completed it in $18.6 \pm 1.6$ days (range 15-22). All birds moulted on the pack ice at locations between $65-71^{\circ} \mathrm{S}$ and $41-50^{\circ} \mathrm{W}$, at a mean distance of $888 \pm 153 \mathrm{~km}$ (range 538-1,081 km) from Signy Island (Fig. 3). During this period, birds were on average $126 \pm 45 \mathrm{~km}$ from the ice edge in areas of very high ice concentration $(93.7 \pm 7.2 \%)$.

During the winter months (April to August), all penguins moved north or north-eastward and were mostly (93\% of 286 weekly GLS locations) located within the advancing sea ice but not in the MIZ in general (Fig. 4); although in the case of four birds, activity data combined with GLS locations suggested that these individuals spent a limited period of time in open water to the north-east of the ice edge (mean period of 16 days, range 3-28 days, between March 29 and May 7, 2005, Fig. 4a). Considering only the complete tracks during this period $(n=15)$, on average, penguins travelled at $109 \pm 23 \mathrm{~km} \mathrm{week}^{-1}$ and were found $216 \pm 133 \mathrm{~km}$ from the ice edge in areas of high sea ice concentration $(87.8 \pm 10.5 \%)$. There was no significant monthly difference in distance of the penguins to the ice edge between April and August (Kruskal-Wallis Test $H 4=3.84, P=0.428$, Table 2). However, during the same time period, there was a significant monthly decrease in the median sea ice concentration in the area occupied by the penguins (Kruskal-Wallis Test $H 4=35.88, P<0.05$, Table 2$)$ and a significant monthly difference in penguin travel speeds (Kruskal-Wallis Test $H 4=11.14, P<0.05)$; the fastest median travel speeds were attained in August $\left(105 \pm 77 \mathrm{~km} \mathrm{week}^{-1}\right)$ and the slowest median travel speeds in May (74 $\pm 80 \mathrm{~km} \mathrm{week}^{-1}$ ). Between April and August, there was considerable variation in the location of penguins; four birds were within $600 \mathrm{~km}$ of their colony and six birds were more than $1,000 \mathrm{~km}$ from their breeding site. By the end of August, birds were widely dispersed in the Weddell Sea, their range extending east to $6^{\circ} \mathrm{W}$ and north to $56^{\circ} \mathrm{S}$, although most individuals (80\%) remained west of $25^{\circ} \mathrm{W}$.

Birds started their return migration during August and September (mean September 9, 2005, $n=12$ ). Travel speeds during the return west to the colony tended to be greater than during their initial journey south to the moult location $\left(41 \pm 15 \mathrm{~km} \mathrm{~d}^{-1}\right.$ compared to $\left.31 \pm 10 \mathrm{~km} \mathrm{~d}^{-1}\right)$, although this was only marginally statistically significant (ANOVA $F_{1,27}=4.2, P=0.05$ ), possibly because of the low sample size. All penguins returned to the vicinity 

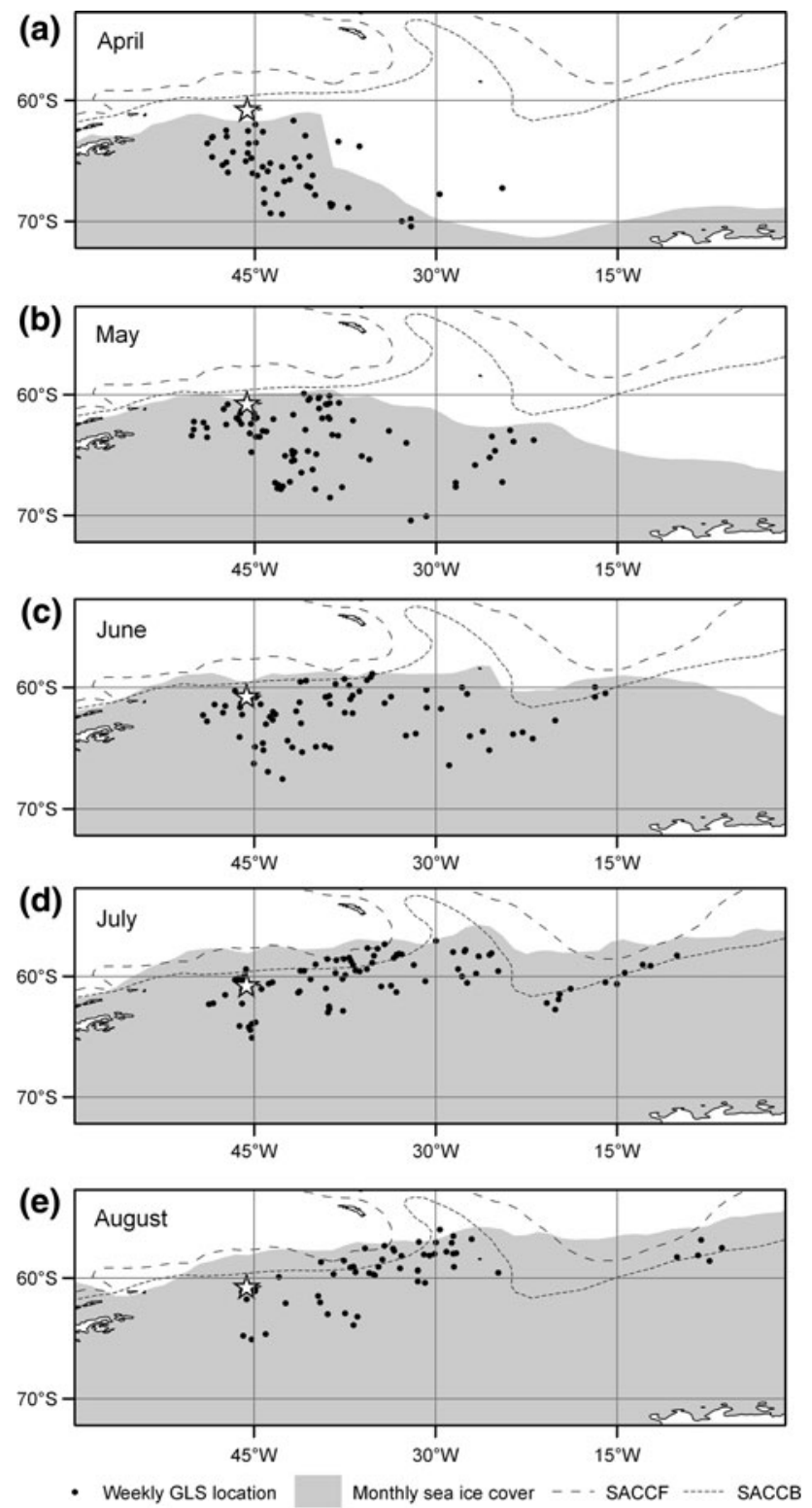

Fig. 4 Distribution of adult Adélie penguins tracked from Signy Island (shown as a white star) during the winter 2005 migration: a April, b May, c June, d July and e August. Also shown are the approximate locations of the southern boundary of the Antarctic Circumpolar Current (ACC) and the southern ACC front (SACCB and SACCF, respectively), reproduced from Orsi et al. (1995) of the colony between 26 September and 22 October (mean return date 9 October, $n=12$, based on GLS data) and spent their first night on land between 8 and 31 October (mean date 19 October, $n=14$, based on immersion data), almost 9 months after departing the colony. There was no significant relationship between distance from colony and start date of return journey (regression analysis $F_{1,10}=0.87, P=0.373$ ). The mean maximum distance travelled from the colony was $1,092 \pm 371 \mathrm{~km}$ (max. $2,235 \mathrm{~km})$.

\section{Discussion}

This study shows that all the post-breeding Adélie penguins that were tracked wintered within the sea ice, travelling distances of between 538 and 1,081 km south of the South Orkney Islands to reach their moult locations. Taking into account the total distances these penguins continued to travel during the rest of the winter before finally returning to their breeding colonies on Signy Island (a mean maximum distance from Signy Island of $1,092 \mathrm{~km}$ ), it is clear that Adélie penguins are capable of travelling considerable distances during the winter, a result also found by previous studies (Davis et al. 1996, 2001; Clarke et al. 2003; Ballard et al. 2010).

Device attachments to diving birds are known to affect aspects of swimming (Wilson et al. 1986, 1997, 2002; Culik and Wilson 1991; Culik et al. 1994). However, the potential influence of our devices on the behaviour of the penguins we tracked is unlikely to be important. Long-term deployment of large tags may have cumulative impacts on behaviour; however, our PTT deployments were relatively short (maximally 59 days after which the devices were lost during moult). In support of this premise, we note that, during the period for which we have comparable tracking data, the movements of all birds carrying PTTs closely resembled those of birds carrying the much smaller GLS tags.

Adélie penguin survival rates vary with gender and age, but are normally between 81 and 97\% (Williams 1995; Ainley et al. 1983). Their breeding status in consecutive
Table 2 Winter migration characteristics of adult Adélie penguins tracked using GLS loggers from Gourlay Peninsula, Signy Island in 2005

Data are means $\pm \mathrm{SD}$ with sample size (number of weekly GLS locations) in parentheses

\begin{tabular}{lllr}
\hline Month & $\begin{array}{l}\text { Distance to } \\
\text { ice edge }(\mathrm{km})\end{array}$ & Ice concentration (\%) & $\begin{array}{r}\text { Travel speed } \\
\left(\mathrm{km} \mathrm{week}^{-1}\right)\end{array}$ \\
\hline April & $173 \pm 104(46)$ & $93.7 \pm 8.3(46)$ & $126 \pm 78(35)$ \\
May & $242 \pm 194(63)$ & $90.3 \pm 16.9(63)$ & $100 \pm 80(63)$ \\
June & $232 \pm 183(58)$ & $89.1 \pm 15.1(58)$ & $124 \pm 88(56)$ \\
July & $212 \pm 160(67)$ & $86.8 \pm 17.4(67)$ & $84 \pm 52(62)$ \\
August & $181 \pm 156(45)$ & $76.7 \pm 23.5(42)$ & $115 \pm 77(44)$ \\
\hline
\end{tabular}


years (year $\mathrm{n}$ and year $\mathrm{n}+1$ ) also varies; for males consecutive breeding is above $74 \%$, and for females it is above 82\% (Ainley et al. 1983). Expected GLS recovery rates for Adélie penguins should therefore vary between 59\% (for returning males that do not breed and do not remain near to the nest site) and 97\% (for returning birds that breed) (Williams 1995).

In our study, we only recovered 28 (52\%) devices, marginally less than the minimum expected return rate. However, the seven birds that were recovered with missing GLSs were only identified by their leg bands, and this with difficulty, due to leg feathers covering the bands. Consequently, it is probable that some of the GLS-equipped birds that were not recovered may have been present at their colonies, but that they remained unobserved. The recovery rate is approximately similar to that reported by Ballard et al. (2010) for devices that were retrieved still functioning (42\%).

All study birds displayed a similar migratory behaviour, travelling southward from Signy Island to the edge of the sea ice. Each logger recorded an extended dry period during February and March, at a mean distance of $126 \mathrm{~km}$ from the ice edge within a narrow latitudinal range of $66-70^{\circ} \mathrm{S}$, suggesting that this is the locality where penguins underwent their post-breeding moult (Penney 1967; Ainley 2002). Most Adélie penguins are known to moult on sea ice and not on land (Ainley 2002; Ballard et al. 2010). Consequently, stable sea ice in this region on an annual basis is likely to be an important resource for moulting Adélie penguins. Further, Kooyman et al. (2000) also noted that Emperor penguins (Aptenodytes forsteri) moulted on sea ice in this sector of the Weddell Sea. Thus, this region within the Weddell Gyre may be important for a variety of species in autumn. Sea ice concentration is known to be changing in this region (Turner et al. 2009).

All study birds spent the subsequent post-moult winter months within the expanding sea ice, in areas of similar ice concentration $(>80 \%)$ to those of penguins in the Ross Sea region (75-85\%; Ballard et al. 2010). All penguins in our study occupied a narrow boundary region, on average $216 \mathrm{~km}$ from the ice edge. This was a similar distance to the areas used by wintering penguins in the north western Weddell Sea (Ainley et al. 1993) but less than the $500 \mathrm{~km}$ distance from ice edge reported for penguins in the Ross Sea (Ballard et al. 2010). No birds returned to their colonies during winter, all remaining continuously at sea until September/October, a period of approximately 7 months after the end of the moult in February/March. The large variation in dispersal distance during this period may reflect differences in extrinsic influences, in particular the speed and direction of ice advance in that region, or intrinsic factors such as age, quality or preferences of individuals (Phillips et al. 2005, 2006).
We found that penguins travelled more slowly whilst moving through sea ice than when travelling through open water. We suggest that this may result because of a number of reasons: (a) penguins may be actively foraging whilst travelling through ice-sea ice being their preferred foraging habitat (Kerry et al. 1995; Davis et al. 1996, 2001; Clarke et al. 2003) — causing them to travel more slowly; (b) penguins may have difficulty in negotiating ice flows and may have to take a circuitous route; (c) birds may spend some of their time travelling out of water, walking over dense pack ice; or, (d) penguins may actively avoid apex predators such as leopard seals by hauling out on ice floes. Although only marginally statistically significant, the mean travel speeds tended to be greater for individuals during the return journey to Signy Island, compared with those recorded during the outward migration. After birds leave their colony they need to rebuild their reserves after the breeding season and prior to their moult when they will undergo considerable physiological demands (Penney 1967; Williams 1995). Increased foraging effort therefore potentially results in a reduction in penguin travel speed; a similar result has also been noted previously by Wilson (1995).

During the time period that penguins begin to move away from their colonies (approximately late December to early February), day length shortens; this cue has been suggested to be the stimulus that Adélie penguins use to initiate postbreeding migratory behaviour (Ainley 2002; Ballard et al. 2010). Conversely, the return migration is also thought to be initiated by a lengthening of the photoperiod in many high latitude bird species (Murton and Westwood 1977; Ainley 2002). Thus, all penguins begin their return journey towards Signy Island around the approximate time of the spring equinox (August/September).

Previous work has shown that Adélie penguins feed on krill, fish and cephalopods during winter months in the Scotia-Weddell Confluence region (Ainley et al. 1992), and consequently rely upon successful krill recruitment (Croxall et al. 1988; Murphy et al. 2004). Antarctic krill may be found at high concentrations near the ice edge in winter (Marschall 1988; Tynan 1998; Nicol et al. 2000). Further, krill have also been located under winter sea ice (Marschall 1988; Daly and Macaulay 1991), with the highest concentrations found within $200 \mathrm{~km}$ of the outer edge of the pack (Daly and Macaulay 1991; Brierley et al. 2002). As such, it is plausible that the high concentration of prey in the outer edge of the pack would explain the penguins' preference for this zone.

Adélie penguin movements throughout the winter months appeared to be very closely related to the distribution of sea ice, a point noted previously by many authors (Ainley et al. 1998; Davis et al. 2001; Clarke et al. 2003; Ballard et al. 2010), and also noted from ship-based 
observations (Ainley et al. 1993, 1994; Fraser et al. 1992; Van Dam and Kooyman 2004). During the middle of the winter (April to August), all of our GLS study birds moved north or north-eastward staying approximately at the edge of the expanding sea ice. Our result therefore confirms earlier assertions that this habitat is preferred (Joiris 1991; Ainley et al. 1993, 1994).

We suggest that Adélie penguins breeding in the South Orkney Islands have a common winter dispersal strategy, moving first southward to moult locations within the sea ice, before moving northwards with the advance of the pack. Certainly, all penguins travelled in a common direction and occupied a broadly similar latitudinal band of sea ice. This suggests the possibility of Adélie penguins from Signy Island sharing a common moulting location and winter feeding ground. Similar assertions have also been suggested for Adélie penguins breeding in the Ross Sea (Davis et al. 1996, 2001; Ballard et al. 2010) and East Antarctica (Kerry et al. 1995; Clarke et al. 2003).

This study provides the first indication of both the moult locations and winter dispersal of Adélie penguins for this sector of the Antarctic. The clear dependence of Adélie penguins on sea ice for both moulting and foraging means that any further reductions in either sea ice distribution or concentration, resulting from climate change, would potentially impose increased pressure upon these populations (Forcada et al. 2006; Hinke et al. 2007; Forcada and Trathan 2009). Predicted future declines in krill numbers in the Scotia Sea, associated with more frequent warm periods and the shorter duration of winter sea ice (Quetin and Ross 2001, 2003; Atkinson et al. 2004, 2008; Murphy et al. 2007) may reduce birds' abilities to rebuild body reserves in time for the succeeding breeding season. Continued future declines in breeding success and over-winter survival are likely consequences (Fraser and Hofmann 2003; Smith et al. 2003; Lynnes et al. 2004; Forcada et al. 2006; Forcada and Trathan 2009). Further research will be necessary to determine whether or not Adélie penguins consistently utilize the same migratory routes and wintering grounds in different years. Such knowledge will be necessary to predict the vulnerability of Adélie penguins in this region, both now and into the future.

Acknowledgments We thank all the members of the Signy Island Research Station, British Antarctic Survey (BAS), during 2004-2005. Particular thanks are extended to Dirk Briggs, Helen Taylor, Andrew Fleming, Tanja Pangerc, Renuka Badhe, Richard Phillips, Norman Ratcliffe and Sue Gregory for their invaluable support, advice and helpful comments. This paper is a contribution to the Ecosystems Programme at BAS.

Open Access This article is distributed under the terms of the Creative Commons Attribution Noncommercial License which permits any noncommercial use, distribution, and reproduction in any medium, provided the original author(s) and source are credited.

\section{References}

Afanasyev V (2004) A miniature daylight level and activity data recorder for tracking animals over long periods. Mem Nat Inst Pol Res 58:227-233

Ainley DG (2002) The Adelie penguin: bellwether of climate change. Columbia University Press, New York

Ainley DG, LeResche RE, Sladen WJL (1983) Breeding biology of the Adelie penguin. University of California Press, Berkeley

Ainley DG, Ribic CA, Fraser WR (1992) Does prey preference affect habitat choice in Antarctic seabirds. Mar Ecol Prog Ser 90: 207-221

Ainley DG, Ribic CA, Spear LB (1993) Species-habitat relationships among Antarctic seabirds - a function of physical or biological factors. Condor 95:806-816

Ainley DG, Ribic CA, Fraser WR (1994) Ecological structure among migrant and resident seabirds of the Scotia-Weddell confluence region. J Anim Ecol 63:347-364

Ainley DG, Wilson PR, Barton KJ, Ballard G, Nur N, Karl B (1998) Diet and foraging effort of Adelie penguins in relation to pack-ice conditions in the southern Ross Sea. Polar Biol 20:311-319

Atkinson A, Siegel V, Pakhomov E, Rothery P (2004) Long-term decline in krill stock and increase in salps within the Southern Ocean. Nature 432:100-103

Atkinson A, Siegel V, Pakhomov EA, Rothery P, Loeb V, Ross RM, Quetin LB, Schmidt K, Fretwell P, Murphy EJ, Tarling GA, Fleming AH (2008) Oceanic circumpolar habitats of Antarctic krill. Mar Ecol Prog Ser 362:1-23

Ballard G, Toniolo V, Ainley DG, Parkinson CL, Arrigo KR, Trathan PN (2010) Responding to climate change: Adelie penguins confront astronomical and ocean boundaries. Ecology 91: 2056-2069

Barlow KE, Croxall JP (2002) Seasonal and interannual variation in foraging range and habitat of macaroni penguins Eudyptes chrysolophus at South Georgia. Mar Ecol Prog Ser 232:291-304

Boersma PD (2008) Penguins as marine sentinels. Bioscience 58:597-607

Bost CA, Thiebot JB, Pinaud D, Cherel Y, Trathan PN (2009) Where do penguins go during the inter-breeding period? Using geolocation to track the winter dispersion of the macaroni penguin. Biology Lett 5:473-476

Brierley AS, Fernandes PG, Brandon MA, Armstromg F, Millard NW, McPhail SD, Stevenson P, Pebody M, Perrett J, Squires M, Bone DG, Griffiths G (2002) Antarctic krill under sea ice: elevated abundance in a narrow band just south of ice edge. Science 295:1890-1892

Clarke J, Manly B, Kerry K, Gardner H, Franchi E, Corsolini S, Focardi S (1998) Sex differences in Adelie penguin foraging strategies. Polar Biol 20:248-258

Clarke J, Kerry K, Fowler C, Lawless R, Eberhard S, Murphy R (2003) Post-fledging and winter migration of Adelie penguins Pygoscelis adeliae in the Mawson region of East Antarctica. Mar Ecol Prog Ser 248:267-278

Clarke A, Murphy EJ, Meredith MP, King JC, Peck LS, Barnes DKA, Smith RC (2007) Climate change and the marine ecosystem of the western Antarctic Peninsula. Philos Trans R Soc Lond B Biol Sci 362:149-166

Cook AJ, Fox AJ, Vaughan DG, Ferrigno JG (2005) Retreating glacier fronts on the Antarctic Peninsula over the past halfcentury. Science 308:541-544

Croxall JP, McCann TS, Prince PA, Rothery P (1988) Reproductive performance of seabirds and seals at South Georgia and Signy Island, South Orkney islands, 1976-1978: implications for Southern Ocean monitoring studies. In: Sahrhage D (ed) 
Antarctic ocean resources variability. Springer-Verlag, Berlin, pp 261-285

Croxall JP, Trathan PN, Murphy EJ (2002) Environmental change and Antarctic seabird populations. Science 297:1510-1514

Culik B, Wilson RP (1991) Swimming energetics and performance of instrumented Adelie penguins (Pygoscelis-Adeliae). J Exp Biol $158: 355-368$

Culik BM, Bannasch R, Wilson RP (1994) External devices on penguins-how important is shape. Mar Biol 118:353-357

Daly KL, Macaulay MC (1991) Influence of physical and biological mesoscale dynamics on the seasonal distribution and behavior of Euphausia-Superba in the Antarctic marginal ice-zone. Mar Ecol Prog Ser 79:37-66

Davis LS, Boersma PD, Court GS (1996) Satellite telemetry of the winter migration of Adelie penguins (Pygoscelis adeliae). Polar Biol 16:221-225

Davis LS, Harcourt RG, Bradshaw CJA (2001) The winter migration of Adelie penguins breeding in the Ross Sea sector of Antarctica. Polar Biol 24:593-597

Ducklow HW, Baker K, Martinson DG, Quetin LB, Ross RM, Smith RC, Stammerjohn SE, Vernet M, Fraser W (2007) Marine pelagic ecosystems: the West Antarctic Peninsula. Philos Trans R Soc Lond B Biol Sci 362:67-94

Forcada J, Trathan PN (2009) Penguin responses to climate change in the Southern Ocean. Glob Chang Biol 15:1618-1630

Forcada J, Trathan PN, Reid K, Murphy EJ, Croxall JP (2006) Contrasting population changes in sympatric penguin species in association with climate warming. Glob Chang Biol $12: 411-423$

Forcada J, Trathan PN, Murphy EJ (2008) Life history buffering in Antarctic mammals and birds against changing patterns of climate and environmental variation. Glob Chang Biol 14:2473-2488

Fraser WR, Hofmann EE (2003) A predator's perspective on causal links between climate change, physical forcing and ecosystem response. Mar Ecol Prog Ser 265:1-15

Fraser WR, Trivelpiece WZ, Ainley DG, Trivelpiece SG (1992) Increases in Antarctic penguin populations-reduced competition with whales or a loss of sea ice due to environmental warming. Polar Biol 11:525-531

Gille ST (2002) Warming of the Southern Ocean since the 1950s. Science 295:1275-1277

Hinke JT, Salwicka K, Trivelpiece SG, Watters GM, Trivelpiece WZ (2007) Divergent responses of Pygoscelis penguins reveal a common environmental driver. Oecologia 153:845-855

Jenouvrier S, Barbraud C, Weimerskirch H (2006) Sea ice affects the population dynamics of Adelie penguins in Terre Adelie. Polar Biol 29:413-423

Joiris CR (1991) Spring distribution and ecological role of seabirds and marine mammals in the Weddell Sea, Antarctica. Polar Biol $11: 415-424$

Kerry KR, Clarke JR, Else GD (1995) The foraging range of Adelie penguins at Bechervaise Island, MacRobertson Land, Antarctica as determined by satellite telemetry In: Dann P, Norman FI, Reilly PN (ed) Penguins: ecology and management. SurreyBeatty, Sydney, pp 216-243

Kooyman GL, Hunke EC, Ackley SE, van Dam RP, Robertson G (2000) Moult of the emperor penguin: travel, location, and habitat selection. Mar Ecol Prog Ser 204:269-277

Lishman GS (1985) The comparative breeding biology of Adelie and chinstrap penguins Pygoscelis-Adeliae and Pygoscelis-Antarctica at Signy Island, South Orkney Islands. Ibis 127:84-99

Lynnes AS, Reid K, Croxall JP, Trathan PN (2002) Conflict or co-existence? Foraging distribution and competition for prey between Adelie and chinstrap penguins. Mar Biol 141:1165-1174
Lynnes AS, Reid K, Croxall JP (2004) Diet and reproductive success of Adelie and chinstrap penguins: linking response of predators to prey population dynamics. Polar Biol 27:544-554

Marschall HP (1988) The overwintering strategy of Antarctic krill under the pack-ice of the Weddell Sea. Polar Biol 9:129-135

McConnell BJ, Chambers C, Fedak MA (1992) Foraging ecology of southern elephant seals in relation to the bathymetry and productivity of the Southern-Ocean. Antarct Sci 4:393-398

Murphy EJ, Clarke A, Symon C, Priddle J (1995) Temporal variation in Antarctic sea-ice - analysis of a long-term fast-ice record from the South-Orkney Islands. Deep-Sea Res Pt I 42:1045-1062

Murphy EJ, Thorpe SE, Watkins JL, Hewitt R (2004) Modeling the krill transport pathways in the Scotia Sea: spatial and environmental connections generating the seasonal distribution of krill. Deep-Sea Res Pt II 51:1435-1456

Murphy EJ, Trathan PN, Watkins JL, Reid K, Meredith MP, Forcada J, Thorpe SE, Johnston NM, Rothery P (2007) Climatically driven fluctuations in Southern Ocean ecosystems. Philos Trans R Soc Lond B Biol Sci 274:3057-3067

Murton RK, Westwood NJ (1977) Avian breeding cycles. Clarendon Press, Oxford

Nicol S, Pauly T, Bindoff NL, Wright S, Thiele D, Hosie GW, Strutton PG, Woehler E (2000) Ocean circulation off east Antarctica affects ecosystem structure and sea-ice extent. Nature 406:504-507

Orsi AH, Whitworth T, Nowlin WD (1995) On the meridional extent and fronts of the Antarctic Circumpolar Current. Deep-Sea Res Pt I 42:641-673

Penney RL (1967) Molt in the Adelie penguin. Auk 84:61-71

Phillips RA, Silk JRD, Croxall JP, Afanasyev V, Briggs DR (2004) Accuracy of geolocation estimates for flying seabirds. Mar Ecol Prog Ser 266:265-272

Phillips RA, Silk JRD, Croxall JP, Afanasyev V, Bennett VJ (2005) Summer distribution and migration of nonbreeding albatrosses: individual consistencies and implications for conservation. Ecology 86:2386-2396

Phillips RA, Silk JRD, Croxall JP, Afanasyev V (2006) Year-round distribution of white-chinned petrels from South Georgia: relationships with oceanography and fisheries. Biol Conserv 129:336-347

Quetin LB, Ross RM (2001) Environmental variability and its impact on the reproductive cycle of Antarctic krill. Am Zool 41:74-89

Quetin LB, Ross RM (2003) Episodic recruitment in Antarctic krill Euphausia superba in the Palmer LTER study region. Mar Ecol Prog Ser 259:185-200

Smith RC, Fraser WR, Stammerjohn SE (2003) Climate variability and ecological response of the marine ecosystem in the Western Antarctic Peninsula (WAP) region. In: Greenland D, Goodin DG, Smith RC (eds) Climate variability and ecosystem response at long-term ecological research sites. Oxford University Press, Oxford, pp 158-173

Spreen G, Kaleschke L, Heygster G (2008) Sea ice remote sensing using AMSR-E 89-GHz channels. J Geophys Res-Oceans. doi: 10.1029/2005JC003384

Stammerjohn SE, Martinson DG, Smith RC, Iannuzzi RA (2008a) Sea ice in the western Antarctic Peninsula region: spatio-temporal variability from ecological and climate change perspectives. Deep-Sea Res Part II 55:2041-2058

Stammerjohn SE, Martinson DG, Smith RC, Yuan X, Rind D (2008b) Trends in Antarctic annual sea ice retreat and advance and their relation to El Nino-Southern Oscillation and Southern Annular Mode variability. J Geophys Res-Oceans 113:1-20

Trathan PN, Croxall JP, Murphy EJ (1996) Dynamics of Antarctic penguin populations in relation to interannual variability in sea ice distribution. Polar Biol 16:321-330 
Turner J (2004) The El Nino-southern oscillation and Antarctica. Int J Climatol 24:1-31

Turner J, Comiso JC, Marshall GJ, Lachlan-Cope TA, Bracegirdle T, Maksym T, Meredith MP, Wang ZM, Orr A (2009) Non-annular atmospheric circulation change induced by stratospheric ozone depletion and its role in the recent increase of Antarctic sea ice extent. Geophys Res Lett. doi:10.1029/2009GL037524

Tynan CT (1998) Ecological importance of the Southern Boundary of the Antarctic Circumpolar Current. Nature 392:708-710

Van Dam RP, Kooyman GL (2004) Latitudinal distribution of penguins, seals and whales observed during a late autumn transect through the Ross Sea. Antarct Sci 16:313-318

Vaughan DG, Marshall GJ, Connolley WM, King JC, Mulvaney R (2001) Climate change-Devil in the detail. Science 293: 1777-1779

Wienecke BC, Lawless R, Rodary D, Bost CA, Thomson R, Pauly T, Robertson G, Kerry KR, LeMaho Y (2000) Adelie penguin foraging behaviour and krill abundance along the Wilkes and Adelie land coasts, Antarctica. Deep-Sea Res Pt II 47:2573-2587

Williams TD (1995) The penguins. Oxford University Press, Oxford
Wilson RP (1995) Foraging ecology. In: Williams TD (ed) The penguins. Oxford University press, Oxford, pp 81-106

Wilson RP, Grant WS, Duffy DC (1986) Recording devices on freeranging marine animals-does measurement affect foraging performance. Ecology 67:1091-1093

Wilson RP, Putz K, Peters G, Culik B, Scolaro JA, Charrassin JB, Ropert-Coudert Y (1997) Long-term attachment of transmitting and recording devices to penguins and other seabirds. Wildl Soc Bull 25:101-106

Wilson RP, Gremillet D, Syder J, Kierspel MAM, Garthe S, Weimerskirch H, Schafer-Neth C, Scolaro JA, Bost CA, Plotz J, Nel D (2002) Remote-sensing systems and seabirds: their use, abuse and potential for measuring marine environmental variables. Mar Ecol Prog Ser 228:241-261

Yuan XJ (2004) ENSO-related impacts on Antarctic sea ice: a synthesis of phenomenon and mechanisms. Antarct Sci 16: 415-425

Yuan XJ, Martinson DG (2000) Antarctic sea ice extent variability and its global connectivity. J Climate 13:1697-1717 